\title{
THE INFLUENCE OF A DIET OF MIXED FEED CONTAINING ZEOLITE ON THE COURSE OF
} CECAL COCCIDIOSIS IN BROILERS

\author{
NEŠIĆ V, ALEKSIĆ Z, DIMITRIJEVIĆ SANDA, KNEŽEVIĆ MILIJANA, ILIĆ TAMARA and \\ RESANOVIĆ RADMILA
}

Faculty of Veterinary Medicine, Belgrade

(Received 25 May, 2003)

In order to investigate cecal coccidiosis in broilers fed zeolite mixtures, two experiments were performed. The first was carried out in vitro, where the concentration of anticoccidial medicine not adsorbed by zeolites was determined by a spectrophotometric method. In the second experiment 100 one-day old broilers were divided into two groups that were fed with mixed feed containing the anticoccidial (salinomycin-Na) with or without a zeolite additive.

Two to 7 days after artificial infection with an Eimeria tenella culture, the birds were killed and pathoanatomical, pathohistological and coprological investigations carried out.

The results showed that the intensity of infection was more pronounced in animals that received salinomycin-Na and zeolite in their feed than in those that received no zeolite. Both the experiment in vitro as well as the coprological investigation showed that bonding of salinomycin-Na by zeolite occurred, leaving a smaller amount of anticoccidial, that was not able to provide the anticipated protective effect.

Key words: broilers, cecal coccidiosis, salinomycin-Na, zeolite

\section{INTRODUCTION}

In modern poultry farming conditions cecal coccidiosis of broilers is one of the most frequent parasitic diseases and an important medical and economic problem (Daszak, 1999, Calnek, 1997, Jordan, 1990).

Cecal coccidiosis prophylaxis is achieved by producing animals immune to the disease, by vaccination, by applying general hygienic measures, proper nutrition, using modern technology in production and adding anticoccidial agents to the mixed feed. Nowdays, a large number of anticoccidial agents of different chemical composition is available, among which ionophores (polyether antibiotics) are the most efficient and most commonly used.

Salinomycin- $\mathrm{Na}$, an ionophore frequently used to prevent coccidiosis, is active during the period of asexual development i.e. schizogony and kills merozoites (Long and Jeffers, 1982). In order to obtain complete efficacy, the medication must be used homogenously mixed into the feed, from the first day of life of the broilers and continually during the fattening period (Melhorn et al. 1983). 
At the same time, in order to prevent certain types of mycotoxicosis, improve health conditions as well as obtain better production results, notable success has been obtained in recent years by adding natural minerals of the zeolite type to the complete mixed feed. Of all the known zeolite minerals, the most widely applied is modified clinoptilolite, wich has a high affinity and level of adsorbance towards certain mycotoxins, ammonia, potassium, heavy metals and radioactive elements (Rodrigues et al. 1997).

Considering the importance of cecal coccidiosis in modern poultry farming and the frequent use of zeolites and polyether antibiotics (ionophores) in mixed feed, we considered it neccesary to investigate this disease in conditions with and without zeolite in the mixed diet. A spectrophotometric method in vitro was first used to determine if and how much zeolite absorbs the anticoccidial salinomycin$\mathrm{Na}$ from the feed, in conditions similar to those in the digestive tract of poultry, followed by an investigation in vivo.

\section{MATERIALS AND METHODS}

The first experiment was set up in vitro and its aim was to determine the degree of adsorption of the applied anticoccidial by zeolite. A "model system" was prepared by adding $5 \mathrm{~g}$ of zeolite to $1 \mathrm{~kg}$ of broiler feed $(0.5 \%)$ into which a preventive dose of anticoccidial salinomycin-Na $60 \mathrm{mg} / \mathrm{kg}$ was previously mixed. By adding the standard buffer $(\mathrm{pH}=3)$ the electrochemical reaction of the surroundings was adjusted to the value characteristic for gastric juice of poultry.

The concentration of "unbound" salinomycin-Na (in solution) was determined by a spectrophotometric method based on the original analytic method of the producers of the salinomycin based preparation (Hoechst, Germany, number 5/1989), using a spectrophotometer (SPEKOL 21 MA 9521), for measurement of the color intensity formed in the reaction of salinomycin-Na with vanillin at $520 \mathrm{~nm}$ (Konstadinović, 1998).

For the second experiment in vivo a total of 100 one-day-old "Hybro" provenience broilers were used. The broilers were kept in metal cages with a wire flooring of standard dimensions, and animal hygiene was in complete accordance with the technological normative (Euribrid, 1989). The broilers were fed a complete mixed feed for broiler fattening - BS, of standard raw material and chemical content, which completely met the needs of this category (NRC, 1993), with a salinomycin-Na supplement.

This consisted of $60 \mathrm{ppm}$ of anticoccidiosis Sacox ${ }^{\circledR}$ (Hoechst) which contained, as the active substance, $120 \mathrm{~g}$ salinomycin-sodium per $\mathrm{kg}$.

The zeolite supplement was a modified clinoptilolite from Zlatokop, Vranjska Banja. The supplement was ground to a particle size less than $10 \mu \mathrm{m}$ for $75 \%$ of the sample. The cation change capacity of the applied zeolite is shown in Table 1. 
Acta Veterinaria (Beograd), Vol. 53. No. 5-6, 377-383, 2003.

Nešić $\mathrm{V}$ et al. The influence of a diet of mixed feed containing zeolite

on the course of cecal coccidiosis in broilers

Table 1. Capacity of cation change of the clinoptilolite supplement

\begin{tabular}{||c|c|c|c|c|c||}
\hline Cation & $\mathrm{K}^{+}$ & $\mathrm{Na}^{+}$ & $\mathrm{Ca}^{++}$ & $\mathrm{Mg}^{++}$ & Total \\
\hline \hline $\begin{array}{c}\text { Capacity } \\
\text { (meq/100g) }\end{array}$ & 17.3 & 82.6 & 49.5 & 16.8 & 166.2 \\
\hline
\end{tabular}

The chemical composition of the modified clinoptilite was determined using an ARL 900 spectrometer and is shown in Table 2.

Table 2. Chemical composition of modified clinoptilite (\%)

\begin{tabular}{||c|c|c|c|c|c|c|c|c|c|c||}
\hline \hline $\mathrm{SiO}_{2}$ & $\mathrm{Al}_{2} \mathrm{O}_{3}$ & $\mathrm{Fe}_{2} \mathrm{O}_{3}$ & $\mathrm{TiO}_{2}$ & $\mathrm{MnO}$ & $\mathrm{CaO}$ & $\mathrm{MgO}$ & $\mathrm{Na}_{2} \mathrm{O}$ & $\mathrm{K}_{2} \mathrm{O}$ & $\mathrm{P}_{2} \mathrm{O}_{3}$ & L.I. \\
\hline \hline 64.21 & 11.48 & 0.88 & 0.25 & 0.03 & 4.55 & 1.45 & 1.71 & 1.29 & 0.05 & 14.0 \\
\hline
\end{tabular}

The chicks were divided into two groups, with 50 birds in each group. The diet for group I included zeolite added (0.5\%) whereas the broilers in group II received no zeolite.

After a preparation period of 14 days, the broilers in each group were divided into two subgroups of 10 and 40 animals ( $a$ and b). Subgroups la and Ila were the control uninfected groups, while the broilers in subgroups Ib and IIb were inoculated with $E$. tenella culture at 14 days old using a plastic probe placed directly into the crop. $2 \mathrm{ml}$ of inoculant containing $4 \times 10^{5}$ of sporulated oocysts of E.tenella was administered to each bird.

Starting at 2 days after infection, six of these infected animals from each treatment were sacrificed each day until day 7, that is at 16 to 21 days of the experiment. Immediately after sacrifice an autopsy was performed as well as a detailed pathoanatomical examination. In the shortest possible time, cecum tissue samples were taken for pathohistological examination. The samples were fixed in $10 \%$ formalin and molded by a standard technique in paraffin. Sections of the tissue samples, 5-8 $\mu \mathrm{m}$, were stained with hematoxylin-eosin (HE).

On the seventh day after infection fecal samples were taken from animals in subgroups $\mathrm{Ib}$ and $\mathrm{Ilb}$ and examined using a standard concentration technique. The number of parasite elements per gram of feces was determined using the McMaster method (Dimitrijević, 1999).

\section{RESULTS}

In Table 3 the results of the in vitro experiments to determine the adsorption of salinomycin-Na to the surface of the zeolite in a model system depending are given. 
Table 3. The time course of adsorption of salinomycin-Na by zeolites in vitro

\begin{tabular}{||c|c|c||}
\hline Experimental model system & Time of exposure (min) & $\begin{array}{c}\text { \% of bound salinomycin-Na } \\
\pm \text { SD }\end{array}$ \\
\hline \hline $\begin{array}{c}\text { zeolite 0.5\% } \\
\text { salinomycin-Na 60ppm } \\
\mathrm{pH}=3 \\
\mathrm{t}=41^{\circ} \mathrm{C}\end{array}$ & 0 & $83.2 \pm 1.3$ \\
\cline { 2 - 3 } & 30 & $92.7 \pm 1.0$ \\
\cline { 2 - 3 } & 60 & $95.4 \pm 0.9$ \\
\hline
\end{tabular}

SD - standard deviation

Table 3 shows a very high level of adsorption of salinomycin-Na by zeolite at the moment of contact (83.2\%). Moreover, the adsorption level increased with time of exposure, so that at 120 minutes it reached $96 \%$.

In Table 4 the time course of appearance of pathoanatomical changes after infection of the chicks with E. tenella is shown. In subgroup Ilb the pathoanatomical findings were mostly negative, except for enlargement of the cecal tonsils and bursa Fabricii, as well as late minor changes in the ceca. However, in subgroup lb there was disturbance of health with clinical signs of illness and the pathoanatomical findings indicated the typical characteristics of cecal coccidiosis.

Table 4. Chronological order of pathoanatomical changes observed after E. tenella infection

\begin{tabular}{|c|c|c|}
\hline \multirow{2}{*}{ Day } & \multicolumn{2}{|c|}{ Subgroup } \\
\hline & $\mathrm{lb}$ & $\mathrm{Ilb}$ \\
\hline 2. & no changes & no changes \\
\hline 3. & lymph tissue of tonsils hyperplastic & $\begin{array}{l}\text { bursa Fabricii and cecal tonsils enlar- } \\
\text { ged }\end{array}$ \\
\hline 4. & $\begin{array}{l}\text { shortened and thickened ceca, the mu- } \\
\text { cous membrane thickened with occa- } \\
\text { sional bleeding }\end{array}$ & $\begin{array}{l}\text { bursa Fabricii and cecal tonsils enlar- } \\
\text { ged }\end{array}$ \\
\hline 5. & $\begin{array}{l}\text { shortened and thickened ceca a bluish } \\
\text { bruised color with a bloodied content in } \\
\text { the lumen; cecal tonsils considerably } \\
\text { enlarged }\end{array}$ & Cecal tonsils enlarged \\
\hline 6. & $\begin{array}{l}\text { shortened and thickened ceca a bluish } \\
\text { bruised color with a bloodied content in } \\
\text { the lumen; cecal tonsils considerably } \\
\text { enlarged }\end{array}$ & Cecal tonsils enlarged \\
\hline 7. & $\begin{array}{l}\text { ceca a bluish color, edematous walls } \\
\text { with reddened and partly necrotized } \\
\text { mucous membrane, bursa Fabricii and } \\
\text { cecal tonsils enlarged }\end{array}$ & $\begin{array}{l}\text { Ceca slightly enlarged, the content mu- } \\
\text { cilaginous; edematous mucosa and oc- } \\
\text { casionally hyperemic }\end{array}$ \\
\hline
\end{tabular}


Especially significant was the finding of developmental forms of E.tenella on certain days after infection (Table 5). Namely, in animals in subgroup Ilb a slight level of infection was detected and a considerably smaller number of developmental forms of $E$. tenella, than in animals in subgroup lb.

Table 5. Chronological order of appearance of the developmental forms of E.tenella

\begin{tabular}{|c|c|c|}
\hline \multirow{2}{*}{ Day } & \multicolumn{2}{|c|}{ Subgroup } \\
\hline & $\mathrm{Ib}$ & IIb \\
\hline 2. & $\begin{array}{l}\text { trophozytes in the epithelial cells along } \\
\text { the Lieberkuhn crypts }\end{array}$ & $\begin{array}{l}\text { trophozytes at the bases of the Lieber- } \\
\text { kuhn glands in very small numbers }\end{array}$ \\
\hline 3. & $\begin{array}{l}\text { schizonts generation I in the surface } \\
\text { epithelium and the epithelium of the Lie- } \\
\text { berkuhn crypts }\end{array}$ & $\begin{array}{l}\text { trophozytes at the bases of the Lieber- } \\
\text { kuhn glands in very small numbers }\end{array}$ \\
\hline 4. & $\begin{array}{l}\text { schizonts generation II in the epithelial } \\
\text { cells and the Lieberkuhn glands and in } \\
\text { the lamina propria mucosa }\end{array}$ & $\begin{array}{l}\text { small number of schizonts generation II } \\
\text { in the zone of the Lieberkuhn crypts }\end{array}$ \\
\hline 5. & $\begin{array}{l}\text { Schizonts generation II and merozoites } \\
\text { generation II in the necrotic detritus in } \\
\text { most Lieberkuhn glands }\end{array}$ & $\begin{array}{l}\text { small number of schizonts generation II } \\
\text { in the bases of the Lieberkuhn glands } \\
\text { as well as subepithelially }\end{array}$ \\
\hline 6. & $\begin{array}{l}\text { schizonts generation II merozoites gen- } \\
\text { eration II, micro and macrogametes in } \\
\text { the surface epithelium and the epithe- } \\
\text { lium of the Lieberkuhn crypts }\end{array}$ & $\begin{array}{l}\text { schizonts generation II, merozoites ge- } \\
\text { neration II, micro and macrogametes } \\
\text { partially along the lamina propria mu- } \\
\text { cosa }\end{array}$ \\
\hline 7. & $\begin{array}{l}\text { schizonts II and merozoites generation } \\
\text { II, micro and macrogametes, zygotes } \\
\text { and nonsporulated oocysts in the epi- } \\
\text { thelial cells of the Lieberkuhn crypts }\end{array}$ & $\begin{array}{l}\text { small number of schizonts II and mero- } \\
\text { zoites generation II, micro and macro- } \\
\text { gametes, zygotes and nonsporulated } \\
\text { oocysts in the epithelium of the Lie- } \\
\text { berkuhn crypts }\end{array}$ \\
\hline
\end{tabular}

The coprological examination of fresh feces on the seventh day after infection, showed that the number of oocysts per gram of feces (OPG) for animals in subgroup Ib, was 25,000 , but only 1,500 for animals in subgroup llb.

\section{DISCUSSION}

It is known that natural zeolites, because of their high adsorption capacity, large free volume and specific surface, show great ability to binding low concentrations of various materials (Flanigen 1983). Considering that the salinomycin- $\mathrm{Na}$ molecule is very large, that its molecular weight is 772 and that it has a great number of double bonds, the adsorption of salinomycin-Na by zeolite is to be expected. The results of our experiments showed that salinomycin-Na adsorption by zeolite was between 83.2 and $96 \%$, and occured immediately after contact with the zeolite, so that the concentration of salinomycin- $\mathrm{Na}$ in solution did not alter much during the observed time interval. 
Pathoanatomical and pathohistological changes due to $\mathrm{E}$. tenella infection in the animals in subgroup lb, which were given both salinomycin-Na and zeolite in their food, were of stronger intensity than the changes observed determined in animals in subgroup Ilb, which were fed the anticoccidial salinomycin-Na alone. The results of both experiments indicate that salinomycin-Na was bound by zeolite in the animals in group I, after which there was a smaller amount of anticoccidial available, that was not able to provide the desired level of protection. Thus, coprological examination, showed a great difference in the number of E.tenella oocysts present in feces of animals between subgroups $\mathrm{lb}$ and $\mathrm{llb}$.

Even with natural zeolite (modified clinoptilolite) sorbent phenomena inevitably occur, which was confirmed on an artificial ion-exchange resin with streptomycin, polymyxin, erythromycin, canamicin, gentamicin, ampicillin, cephalexin and others (Savickaja et al., 1981). It is also true that natural zeolites are very effective ion-changing sorbents (Minato and Tamura, 1978), because of which we cannot dismiss the possibility that in certain conditions adsorption of antibiotics occurs. Until desorption, a "bonded" antibiotic can be partially or completely biologically inactive. Our assumption that zeolite bonds salinomycin- $\mathrm{Na}$, thus reducing its available dosage, supports the data of Danforth et al. (1977), that low doses of salinomycin-Na do not provide adequate protection against coccidiosis.

Due to the complexity of the mechanisms and the kinetics of adsorption and desorption reactions, especially regarding natural sorbents, which contain various different additives, and particularly when medicine is given simultaneously with the feed, this problem demands further more comprehensive research.

Address for correspondence:

Mr Vladimir Nešić

Faculty of Veterinary Medicine,

Bul JNA 18

11000 Belgrade, Serbia \& Montenegro

e-mail: nesic@vet.bg.ac.yu

\section{REFERENCES}

1. Calnek BW, 1997, Diseases of Poultry, lowa State University Press, lowa, USA.

2. Danforth HD, Ruff MD, Reid WM, Miller RL, 1977, Anticoccidial activity of salinomycin in battery raised broiler chickens, Poult Sci, 56, 926-32.

3. Daszak BV, 1999, Zoite migration during Eimeria tenella infection: Parasite adaption to host defences, Parasitol Tod, 2, 67-72.

4. Dimitrijević S, 1999, Dijagnostika parazitskih bolesti, Fakultet veterinarske medicine, Beograd, 4754.

5. Euribrid, 1989, Tehnički podaci, Netherland, 3-8.

6. Flanigen EM, 1983, Adsorption properties of molecular sieve zeolites: in Zeo - agriculture: use of natural zeolites in agriculture and aquaculture. WG Pond, FA Mumpton, eds., Westview Press, Boulder, Colorado, 55-68.

7. Jordan FTW, 1990, Poultry Diseases, English Language Book Society, London, 226-41.

8. Kostadinović Lj, 1998, Uticaj kokcidiostatika na biohemijske parametre brojlera i određivanje njihovih rezidua u tkivima, Doktorska disertacija, Novi Sad.

9. Long PL, Jeffers TK, 1982, Studies on the stage of action of ionophorous antibiotics against Eimeria. J Parasitol, 68, 363-71. 
Acta Veterinaria (Beograd), Vol. 53. No. 5-6, 377-383, 2003.

10. Melhorn H, Pooch H, Raether W, 1983, The action of polyether ionophorous antibiotics (monensin salinomycin, lasalocid) on developmental stages of Eimeria tenella (Coccidia, Sporozoa) in vivo and in vitro: study by light and electron microscopy, Z Parasitenkd, 69, 457-71.

11. Minato $H$, Tamura $T, 1978$, Production of oxygen and nitrogen with natural zeolites: in Natural zeolites: occurrence, properties, use. LB Sand, FA Mumpton, eds, Pergamon Press, Elmsford, New York, 509-13.

12. National Research Council, 1993, Nutrient requirements of poultry, National Acad. Press, Washington DC.

13. Rodrigues FG et al., 1997, Pharmacological action of modified natural clinoptilolite, Naples Zeolite Meeting '97, Inter Symp on Natural Zeolite, 258-60.

14. Савицкая ЕМ, Яхоншова ЛФ, Ныс ПС, 1981, Ионообменная технология получения биологически активных веществ. Ионный обмен, Наука, Москва, 229-48.

\title{
UTICAJ ISHRANE SMEŠAMA SA ZEOLITOM NA TOK CEKALNE KOKCIDIOZE
} BROJLERA

\author{
NEŠIĆ V, ALEKSIĆ Z, DIMITRIJEVIĆ SANDA, KNEŽEVIĆ MILIJANA, ILIĆ TAMARA i \\ RESANOVIĆ RADMILA
}

\section{SADRŽAJ}

U cilju ispitivanja cekalne kokcidioze brojlera u uslovima ishrane smešama sa zeolitom izvedena su dva ogleda. Prvi ogled je izveden u "in vitro" uslovima, gde je spektrofotometrijskom metodom određivana koncentracija antikokcidijala koji nije adsorbovan od strane zeolita. Drugi ogled je izveden na 100 jednodnevnih brojlera podeljenih u dve grupe, koji su hranjeni krmnom smešom sa dodatkom antikokcidijala i zeolita u zavisnosti od ogledne grupe.

Nakon veštačke infekcije kulturom $E$. tenella, vršena su patoanatomska, patohistološka i koprološka ispitivanja žrtvovanih jedinki od drugog do sedmog dana posle infekcije.

Rezultati ispitivanja su pokazali da je intenzitet promena bio izraženiji kod jedinki ogledne grupe koje su u hrani dobijale salinomycin-Na i zeolit u odnosu na jedinke koje su dobijale samo salinomycin-Na. I rezultati "in vitro" ogleda i koprološkog ispitivanja su pokazali da je došlo do vezivanja salinomycin-Na od strane zeolita, usled čega je na raspolaganju ostala manja količina antikokcidijala, koja nije bila u stanju da pruži očekivani zaštitni efekat. 